\title{
RESPON PERTUMBUHAN DAN HASIL TANAMAN BUNCIS TEGAK (Phaseolus vulgaris L.) TERHADAP BERBAGAI PUPUK ORGANIK SUMBER NITROGEN
}

\author{
Respons of Growth and Production of Common Beans (Phaseolus vulgaris L.) to Various \\ Nitrogen Source Organic Fertilizer
}

\author{
Affandy Sahala Tua Marpaung ${ }^{\mathrm{a}}$, Arifah Rahayu ${ }^{\mathrm{b} *}$, Nur Rochman ${ }^{\mathrm{b}}$ \\ aProgram Studi Agroteknologi, Fakultas Pertania, Universitas Djuanda

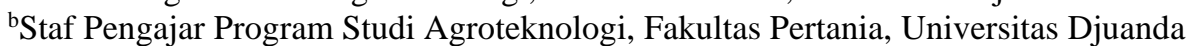 \\ Jalan Tol Ciawi, No. 1 Kotak Pos 35 Ciawi-Bogor, 16720 \\ *Email korespondensi: arifah.rahayu@unida.ac.id
}

Diterima 31 Maret 2021/Disetujui 27 April 2021

\begin{abstract}
ABSTRAK
Penelitian ini bertujuan untuk mempelajari pengaruh jenis pupuk organik sumber $\mathrm{N}$ terhadap pertumbuhan dan produksi tanaman buncis tegak. Penelitian dilaksanakan di Kebun Percobaan Universitas Djuanda, Ciawi, Bogor, Jawa Barat pada bulan Februari-Mei 2019. Penelitian disusun menggunakan Rancangan Acak Lengkap yang terdiri atas 11 taraf yaitu tanpa pupuk, kipahit 100\% R, kirinyuh 100\% R, urine sapi 100\% R, urea $100 \%$ R, kipahit $75 \%$ + urea $25 \%$ R, kirinyuh $75 \%$ + urea $25 \%$ R, urine sapi $75 \%$ + urea $25 \%$ R, kipahit $50 \%+$ urea $50 \%$ R, kirinyuh $50 \%$ + urea $50 \%$ R, urine sapi $50 \%$ + urea $50 \%$ R. Hasil penelitian membuktikan bahwa aplikasi POC sumber nitrogen memiliki hasil yang yang tidak berbeda nyata dengan aplikasi urea 100\% R, sehingga dapat digunakan sebagai alternatif pengganti urea untuk menerapkan sistem nature farming.
\end{abstract}

Kata kunci: kipahit, kirinyuh, urine sapi

\section{ABSTRACT}

This study was aimed at assessing the effects of the application of different types of $N$ source liquid organic fertilizers (LOF) on the growth and production of common beans. The study was conducted at the experimental field of Djuanda University, Bogor, West Java on February-May 2019. A completely randomized design was used. Treatments consisted of 11 levels of fertilizer applications, namely no fertilizer, $100 \% R$ mexican sunflower, $100 \% R$ kirinyuh (Chromolaena odorata), $100 \% R$ cattle urine, $100 \% R$ urea, $75 \% R$ mexican sunflower $+25 \% R$ urea, $75 \% R$ kirinyuh $+25 \% R$ urea, $75 \% R$ cattle urine $+25 \% R$ urea, $50 \% R$ mexican sunflower $+50 \%$ R urea, $50 \% R$ kirinyuh $+50 \% R$ urea, and $50 \% R$ cattle urine $+50 \% R$ urea. Results showed that compared to the use of $100 \% R$ urea, the application of $N$ source LOF did not give any significant effects on all parameters measured. This indicated that $N$ source LOF could be used as urea alternative in natural farming systems.

Keywords : mexican sunflower, kirinyuh, cattle urine

\section{PENDAHULUAN}

Tanaman buncis (Phaseolus vulgaris L.) merupakan sayuran kelompok kacang-kacangan yang banyak diminati masyarakat. Tipe pertumbuhan tanaman buncis dibedakan atas tipe tegak dan tipe merambat. Dibandingkan tipe merambat, buncis tipe tegak memiliki keunggulan, antara lain tidak memerlukan ajir, sehingga dapat menurunkan biaya produksi sebesar $30 \%$ dan populasi tanaman buncis tegak per hektarnya lebih banyak, rata-rata populasinya mencapai $150.000-200.000$ tanaman per hektar, sedangkan populasi per hektar buncis merambat hanya setengahnya (Pitojo 2004). Buncis tegak cocok dibudidayakan di dataran medium, sedangkan buncis rambat cocok dibudidayakan di dataran tinggi.

Produksi tanaman buncis setiap tahun cenderung mengalami penurunan selama periode 2014-2017. Antara tahun 2014-2017 produksi buncis nasional 
berturut - turut mencapai angka 318.213 ton, 291.314 ton, 275.508 ton, dan 279.039 ton, dengan luas lahan masing - masing sebesar 28.632 ha, 25.645 ha, 25.104 ha, dan 23.746 ha (DJH 2018). Menurut BPS (2015), pada tahun 2014 Indonesia masih mengimpor buncis sebanyak 6,94 ton. Kondisi tersebut mendorong perlunya usaha peningkatan produktivitas buncis melalui budidaya pertanian dengan mengoptimalkan sumberdaya lokal, antara lain dengan menggunakan pupuk organik.

Umumnya petani lebih sering menggunakan pupuk sinteteik, karena pengaruh yang ditimbulkan lebih cepat terlihat. Menurut Sutanto (2002), dampak penggunaan pupuk sintetik yang berlebihan dapat menurunkan kesuburan biologi tanah, memacu perkembangan patogen, menyebabkan keracunan unsur hara dan menurunkan ketahanan tanaman terhadap serangan hama dan penyakit, sebab itu diperlukan upaya peningkatan kesuburan tanah melalui pendekatan nature farming (pertanian ramah lingkungan) dengan cara menambah bahan organik dalam tanah sebagai alternatif pupuk.

Hara utama yang dibutuhkan tanaman adalah nitrogen. Sebagian besar tanaman sayuran termasuk buncis menggunakan pupuk urea sebagai sumber N. Penggunaan urea dapat meningkatkan produksi, tetapi aplikasi yang tidak terkendali dapat menyebabkan degradasi daya dukung dan kualitas tanah, sehingga produktivitas lahan semakin menurun, karena menurunnya kandungan bahan organik tanah (Adi 2013). Pupuk N sintetik juga mudah tercuci, sehingga berakibat buruk pada ekosistem, karena mencemari perairan dan dapat mengganggu keanekaragaman hayati (Gonzalez-Dugo et al. 2010). Kondisi tersebut mendorong perkembangan pertanian organik dengan menggunakan input (pupuk dan pestisida) yang ramah lingkungan, seperti urine sapi, kipahit dan kirinyuh yang dibuat pupuk organik cair (POC).
Kekurangan $\mathrm{N}$ akan menghentikan proses pertumbuhan dan reproduksi. Gejala tanaman yang mengalami kekurangan $\mathrm{N}$ antara lain daun menguning mulai dari daun paling bawah. Perubahan warna ini terjadi akibat hidrolisis kloroplas (Rohmawati 2013). Nitrogen hasil hidrolisis akan dipindahkan dari daun tua ke daun muda. Pupuk organik sumber nitrogen dapat diperoleh dari urine sapi, kompos, dan tanaman penghasil hara $\mathrm{N}$, seperti kipahit (Tithonia diversifolia) dan kirinyuh (Chromolaena odorata).

Penggunaan POC memberikan beberapa keuntungan, misalnya pupuk ini dapat digunakan dengan cara menyiramkannya ke akar maupun disemprotkan ke tanaman (Supriyanto et al. 2014). Hara pada POC lebih cepat tersedia bagi tanaman, terutama nitrogen karena tersedia lebih banyak dalam bentuk $\mathrm{NH}_{4}-\mathrm{N}$ (Matsi 2012). Penggunaan POC menghemat tenaga kerja, karena pemberiannya dapat diaplikasikan bersamaan dengan penyiraman (fertigasi).

Urine sapi mengandung lebih dari $50 \%$ nitrogen dan kalium dari total yang diekskresikan, sedangkan kotoran padatnya lebih banyak mengandung fosfor, yakni sampai $80 \%$ (Lory et al. 2006). Selain itu, proses pengolahan POC yang berasal dari urine cukup mudah dan proses fermentasinya singkat.

Kipahit (Tithonia diversifolia) merupakan gulma yang telah dikembangkan sebagai sumber bahan organik untuk meningkatkan ketersediaan hara (Atmojo 2003). Kipahit dapat dijadikan sebagai tanaman pengendali erosi dan sebagai sumber bahan organik. Sepanjang $70 \mathrm{~cm}$ tajuk teratas mengandung unsur hara yang cukup tinggi yaitu $2,52 \% \mathrm{~N} ; 1,97 \% \mathrm{~K} ; 0,29 \% \mathrm{P} ; 0,51 \%$ $\mathrm{Ca}$; dan 0,39\% Mg (Hakim et al. 2012).

Kirinyuh (Chromolaena odorata L.) merupakan tanaman liar yang berpotensi sebagai sumber bahan organik. Kirinyuh mengandung unsur nitrogen yang tinggi $(2,65 \%)$, sehingga potensial dimanfaatkan sebagai sumber bahan 
organik, karena produksi biomassanya tinggi. Oleh karena itu, penelitian ini bertujuan untuk mengetahui pengaruh pupuk organik cair sumber nitrogen dari urine sapi, tanaman kipahit, dan kirinyuh terhadap pertumbuhan dan hasil tanaman buncis tegak.

\section{MATERI DAN METODE}

Penelitian ini dilaksanakan mulai bulan Februari-Mei 2019. Percobaan lapangan dilakukan di Kebun Percobaan Universitas Djuanda dan pembuatan pupuk organik cair di Seameo-Biotrop Bogor. Analisis N pada POC urine sapi, POC kipahit, dan POC kirinyuh dilaksanakan di Laboratorium Agronomi dan Hortikultura Institut Pertanian Bogor. Alat yang digunakan meliputi alat pengolah tanah, penggaris, timbangan, penyemprot insektisida, alat-alat laboratorium, saringan, ember dan pisau. Bahan yang digunakan adalah kompos, bibit tanaman buncis tegak varietas Balitsa-2, polybag ukuran $30 \mathrm{~cm}$ x $40 \mathrm{~cm}$, kain kasa, media tanam tanah, daun kipahit dan kirinyuh (masing-masing $5 \mathrm{~kg}$ ), urine sapi, arang sekam, dekomposer (EM4), gula merah 1 $\mathrm{kg}$, dan air.

Rancangan yang digunakan adalah rancangan acak lengkap (RAL) satu faktor yang terdiri atas 11 taraf pupuk rekomendasi (R) yaitu tanpa pupuk, kipahit $100 \%$ R, kirinyuh $100 \% \mathrm{R}$, urine sapi $100 \% \mathrm{R}$, urea $100 \% \mathrm{R}$, kipahit $75 \% \mathrm{R}$ + urea $25 \% \mathrm{R}$, kirinyuh $75 \%$ + urea $25 \%$ $\mathrm{R}$, urine sapi $75 \% \mathrm{R}+$ urea $25 \% \mathrm{R}$, kipahit $50 \% \mathrm{R}+$ urea $50 \% \mathrm{R}$, kirinyuh $50 \% \mathrm{R}+$ urea $50 \% \mathrm{R}$, urine sapi $50 \% \mathrm{R}+$ urea $50 \%$ R. Setiap taraf perlakuan diulang empat kali sehingga didapat 44 satuan percobaan, setiap satuan percobaan terdiri atas tiga satuan amatan, sehingga seluruhnya terdapat 132 tanaman. Dosis rekomendasi (100\%) pupuk sintetik untuk tanaman buncis tegak adalah $62 \mathrm{~kg} / \mathrm{ha} \mathrm{N}, 250 \mathrm{~kg} / \mathrm{ha}$ $\mathrm{P}_{2} \mathrm{O}_{5}$ dan $90 \mathrm{~kg} / \mathrm{ha} \mathrm{K}_{2} \mathrm{O}$ yang diketahui optimum untuk tanaman buncis tegak (Susila 2006).
Media tanam yang digunakan adalah tanah + arang sekam dengan perbandingan volume 1:1. Media tanam dimasukkan kedalam polybag ukuran $30 \mathrm{x}$ $40 \mathrm{~cm}$. Pemberian pupuk dasar diberikan seminggu sebelum tanam, pupuk dasar berupa POC sumber $\mathrm{N}$ dan/atau urea, SP36, dan $\mathrm{KCl}$. Penyulaman dilakukan sebelum tanaman berumur 10 HST (hari setelah tanam). Penyiraman dan penyiangan gulman dilakukan kondisional. Aplikasi pemupukan POC dilakukan ketika tanaman berumur 2 MST (minggu setelah tanam) dengan interval pemupukan setiap 2 minggu sekali. Aplikasi dilakukan dengan menyiramkan POC sesuai takaran. Pemupukan diaplikasikan berdasarkan taraf perlakuan. Urea dan POC diberikan secara bertahap, sedangkan pupuk SP-36 dan $\mathrm{KCl}$ diberikan $100 \%$ sebagai pupuk dasar (Rohmawati 2013). Pemberian POC dilakukan dengan cara disiramkan pada tanah. Penghitungan dosis pupuk kimia sintetik dan urine sapi per polybag dihitung dengan mengkonversi kebutuhan pupuk per-tanaman dengan jarak tanam 40 $\mathrm{x} 40 \mathrm{~cm}$ dan kebutuhan $\mathrm{N}$ dalam urea.

Peubah yang diamati pada penelitian ini adalah tinggi tanaman, jumlah daun, luas daun, diameter batang, jumlah bunga, jumlah polong per tanaman, bobot polong basah dan bobot polong kering.

\section{HASIL DAN PEMBAHASAN}

\section{Hasil}

Tinggi tanaman buncis nyata dipengaruhi oleh komposisi pupuk. Pada awal pertumbuhan (2 MST), tinggi tanaman yang diberi $100 \% \mathrm{R}$ urine sapi/kirinyuh dan kombinasi $75 \%$ urine sapi/kipahit/kirinyuh dengan $25 \%$ urea tidak berbeda nyata dengan tanaman yang diberi $100 \% \mathrm{R}$ urea. Pada saat pertumbuhan berikutnya (3-6 MST), tanaman yang diberi perlakuan urine sapi $(100 \%$ / 75\% / 50\% R) dan komposisi kirinyuh $50 \%$ + urea $50 \%$ tidak berbeda nyata dengan urea $100 \% \mathrm{R}$ (Tabel 1). 
Tabel 1. Pertambahan tinggi tanaman buncis pada umur 2-6 MST

\begin{tabular}{|c|c|c|c|c|c|}
\hline \multirow{2}{*}{ Perlakuan } & \multicolumn{5}{|c|}{ Rata-rata tinggi tanaman } \\
\hline & $2 \mathrm{MST}$ & 3 MST & 4 MST & $5 \mathrm{MST}$ & $6 \mathrm{MST}$ \\
\hline$\overline{\mathrm{P} 1 \text { (tanpa pupuk) }}$ & $13,7^{\mathrm{abc}}$ & $19,75^{\mathrm{abc}}$ & $25,42^{\mathrm{abc}}$ & $29,17^{\mathrm{bc}}$ & $30,75^{\mathrm{ab}}$ \\
\hline P2 (urea $100 \%$ ) & $15,04^{\mathrm{e}}$ & $23,912^{\mathrm{d}}$ & $32,42^{\mathrm{e}}$ & $37,42^{\mathrm{e}}$ & $39,75^{\mathrm{de}}$ \\
\hline P3 (kipahit 100\%) & $14,21^{\text {bcde }}$ & $18,83^{\mathrm{abc}}$ & $22,50^{\mathrm{abc}}$ & $28,92^{\mathrm{bc}}$ & $33,58^{\mathrm{abc}}$ \\
\hline P4 (kipahit $75 \%$ + urea $25 \%$ ) & $13,62^{\mathrm{ab}}$ & $20,38^{\mathrm{abcd}}$ & $25,54^{\text {bcd }}$ & $29,71^{\mathrm{bcd}}$ & $32,21^{\mathrm{abc}}$ \\
\hline P5 (kipahit 50\% + urea 50\%) & $13,37^{\mathrm{a}}$ & $21,33^{\mathrm{bcd}}$ & $27,83^{\text {bcde }}$ & $33,42^{\text {cde }}$ & $35,17^{\mathrm{bcd}}$ \\
\hline P6 (kirinyuh 100\%) & $14,58^{\mathrm{de}}$ & $18,67^{\mathrm{ab}}$ & $22,50^{\mathrm{abc}}$ & $28,25^{\mathrm{ab}}$ & $30,75^{\mathrm{ab}}$ \\
\hline P7 (kirinyuh $75 \%+$ urea $25 \%$ ) & $14,54^{\text {cde }}$ & $17,17^{\mathrm{a}}$ & $21,13^{\mathrm{a}}$ & $24,62^{\mathrm{a}}$ & $29,29^{\mathrm{a}}$ \\
\hline P8 (kirinyuh 50\% + urea 50\%) & $14,08^{\text {abcd }}$ & $23,00^{\text {cd }}$ & $31,67^{\mathrm{e}}$ & $36,17^{\mathrm{e}}$ & $40,00^{\text {de }}$ \\
\hline P9 (urine $100 \%$ ) & $14,29^{\text {bcde }}$ & $23,08^{\mathrm{cd}}$ & $31,17^{\mathrm{de}}$ & $35,50^{\mathrm{e}}$ & $38,08^{\mathrm{de}}$ \\
\hline P10 (urine $75 \%$ + urea $25 \%$ ) & $14,20^{\text {bcde }}$ & $24,58^{\mathrm{d}}$ & $31,17^{\mathrm{de}}$ & $34,92^{\mathrm{de}}$ & $37,17^{\text {cde }}$ \\
\hline P11 (urine $50 \%$ + urea $50 \%$ ) & $13,95^{\mathrm{abc}}$ & $26,29^{d}$ & $36,58^{\mathrm{e}}$ & $39,33^{\mathrm{e}}$ & $40,25^{\text {de }}$ \\
\hline
\end{tabular}

Keterangan: Nilai rata-rata pada kolom yang sama diikuti huruf yang sama tidak berbeda nyata menurut uji DMRT pada taraf 5\%

Jumlah daun tanaman buncis nyata dipengaruhi komposisi pupuk. Pada umur 2 MST, jumlah daun pada tanaman yang diberi $100 \% \mathrm{R}$ urea tidak berbeda nyata dengan tanaman yang diberi $100 \%$ kipahit/kirinyuh/urine sapi, kombinasi $75 \%$ kirinyuh/urine sapi dengan $25 \%$ urea, dan kombinasi 50\% kirinyuh / urine sapi dengan $25 \%$ urea. Pada saat pertumbuhan berikutnya (3-6 MST), tanaman yang diberi $50 \% \mathrm{R}$ kirinyuh $+50 \%$ urea dan urine sapi $(100 \%$ / $75 \%$ / 50\%) tidak berbeda nyata dengan tanaman yang diberi pupuk urea 100\% R (Tabel 2).

Tabel 2. Jumlah daun buncis pada umur 2-6 MST

\begin{tabular}{llllll}
\hline \multirow{2}{*}{ Perlakuan } & \multicolumn{5}{c}{ Rata-rata respon jumlah daun tanaman } \\
\cline { 2 - 6 } & $2 \mathrm{MST}$ & $3 \mathrm{MST}$ & $4 \mathrm{MST}$ & $5 \mathrm{MST}$ & $6 \mathrm{MST}$ \\
\hline P1 (tanpa pupuk) & $3,42^{\mathrm{ab}}$ & $3,58^{\mathrm{a}}$ & $3,67^{\mathrm{a}}$ & $4,17^{\mathrm{ab}}$ & $4,33^{\mathrm{a}}$ \\
P2 (urea 100\%) & $4,75^{\mathrm{bc}}$ & $4,92^{\mathrm{c}}$ & $6,00^{\mathrm{cd}}$ & $9,5^{\mathrm{f}}$ & $12,25^{\mathrm{de}}$ \\
P3 (kipahit 100\% & $4,00^{\mathrm{c}}$ & $3,75^{\mathrm{ab}}$ & $4,00^{\mathrm{ab}}$ & $5,75^{\mathrm{abcd}}$ & $5,92^{\mathrm{ab}}$ \\
P4 (kipahit 75\% + urea 25\%) & $3,42^{\mathrm{ab}}$ & $3,25^{\mathrm{a}}$ & $3,33^{\mathrm{a}}$ & $4,08^{\mathrm{a}}$ & $5,58^{\mathrm{ab}}$ \\
P5 (kipahit 50\% + urea 50\%) & $3,17^{\mathrm{a}}$ & $4,17^{\mathrm{abc}}$ & $4,50^{\mathrm{abc}}$ & $6,42^{\mathrm{bcde}}$ & $7,83^{\mathrm{bc}}$ \\
P6 (kirinyuh 100\%) & $4,08^{\mathrm{c}}$ & $4,08^{\mathrm{abc}}$ & $3,75^{\mathrm{a}}$ & $4,17^{\mathrm{ab}}$ & $5,50^{\mathrm{ab}}$ \\
P7 (kirinyuh 75\% + urea 25\%.) & $3,83^{\mathrm{bc}}$ & $3,67^{\mathrm{ab}}$ & $3,75^{\mathrm{a}}$ & $5,25^{\mathrm{abc}}$ & $5,25^{\mathrm{ab}}$ \\
P8 (kirinyuh 50\% + urea 50\%) & $3,58^{\mathrm{abc}}$ & $4,58^{\mathrm{bc}}$ & $5,25^{\mathrm{bcd}}$ & $8,83^{\mathrm{ef}}$ & $12,17^{\mathrm{cde}}$ \\
P9 (urine 100\%) & $3,92^{\mathrm{c}}$ & $4,92^{\mathrm{c}}$ & $5,75^{\mathrm{cd}}$ & $7,33^{\mathrm{cdef}}$ & $9,58^{\mathrm{cd}}$ \\
P10 (urine 75\% + urea 25\%) & $3,92^{\mathrm{c}}$ & $4,92^{\mathrm{c}}$ & $5,92^{\mathrm{cd}}$ & $8,00^{\mathrm{def}}$ & $10,92^{\mathrm{cde}}$ \\
P11 (urine 50\% + urea 50\%) & $3,92^{\mathrm{bc}}$ & $5,00^{\mathrm{c}}$ & $6,08^{\mathrm{d}}$ & $8,67^{\mathrm{ef}}$ & $12,50^{\mathrm{e}}$ \\
\hline
\end{tabular}

Keterangan: Nilai rata-rata pada kolom yang sama diikuti huruf yang sama tidak berbeda nyata menurut uji DMRT pada taraf $5 \%$

Luas daun dan diameter batang tanaman buncis dipengaruhi oleh komposisi pupuk N. Luas daun dan diameter batang tanaman yang diberi kirinyuh $50 \% \mathrm{R}+$ urea $50 \% \mathrm{R}$ dan urine sapi $(100 \%$ / 75\% / 50\% R) tidak berbeda nyata dengan tanaman yang diberi pupuk urea 100\% R (Tabel 3).
Jumlah bunga tanaman buncis nyata dipengaruhi oleh komposisi pupuk pada umur 32 HST dan 38 HST. Tanaman yang diberi pupuk kombinasi 50\% R urea dengan kirinyuh dan urine sapi $(100 / 75 \% / 50 \%$ R) tidak berbeda nyata dengan tanaman yang diberi pupuk urea 100\% R (Tabel 4). 
Tabel 3. Luas daun dan diameter batang tanaman buncis

\begin{tabular}{lcc}
\hline \multirow{2}{*}{ Perlakuan } & \multicolumn{2}{c}{ Rata-rata respon tanaman } \\
\cline { 2 - 3 } P1 (tanpa pupuk) & Luas Daun & Diameter Batang \\
P2 (urea 100\%) & $16,65^{\mathrm{a}}$ & $4,25^{\mathrm{a}}$ \\
P3 (kipahit 100\%) & $39,63^{\mathrm{d}}$ & $6,87^{\mathrm{ef}}$ \\
P4 (kipahit 75\% + urea 25\%) & $28,70^{\mathrm{bc}}$ & $5,65^{\mathrm{bc}}$ \\
P5 (kipahit 50\% + urea 50\%) & $19,44^{\mathrm{ab}}$ & $5,91^{\mathrm{cd}}$ \\
P6 (kirinyuh 100\%) & $28,70^{\mathrm{bc}}$ & $5,86^{\mathrm{cd}}$ \\
P7 (kirinyuh 75\% + urea 25\%) & $26,85^{\mathrm{bc}}$ & $4,87^{\mathrm{ab}}$ \\
P8 (kirinyuh 50\% + urea 50\%) & $16,48^{\mathrm{a}}$ & $4,94^{\mathrm{ab}}$ \\
P9 (urine 100\%) & $41,30^{\mathrm{d}}$ & $7,07^{\mathrm{ef}}$ \\
P10 (urine 75\% + urea 25\%) & $39,63^{\mathrm{d}}$ & $6,57^{\mathrm{def}}$ \\
P11 (urine 50\% + urea 50\%) & $33,33^{\mathrm{cd}}$ & $6,38^{\mathrm{cde}}$ \\
\hline
\end{tabular}

Keterangan: Nilai rata-rata pada kolom yang sama diikuti huruf yang sama tidak berbeda nyata menurut uji DMRT pada taraf $5 \%$

Jumlah dan bobot polong buncis nyata dipengaruhi oleh komposisi pupuk pada panen ke 2 dan 3. Pada panen ke 2, jumlah polong tanaman yang diberi $100 \%$ R kipahit / kirinyuh / urine sapi, komposisi $50 \% \mathrm{R}$ urea dengan kirinyuh / urine sapi tidak berbeda nyata dengan tanaman yang diberi $100 \% \mathrm{R}$ urea. Selanjutnya pada panen ke 3, jumlah polong tanaman yang diberi $100 \% \mathrm{R}$ urine sapi dan kombinasi $50 \% \mathrm{R}$ urea dengan kirinyuh/urine sapi tidak berbeda nyata dengan tanaman yang diberi urea $100 \% \mathrm{R}$ (Tabel 5).

Tabel 4. Jumlah bunga tanaman buncis

\begin{tabular}{|c|c|c|c|c|c|c|}
\hline \multirow{2}{*}{ Perlakuan } & \multicolumn{5}{|c|}{ Rata-rata jumlah bunga tanaman } & \multirow[b]{2}{*}{$38 \mathrm{HST}$} \\
\hline & 28 HST & $30 \mathrm{HST}$ & $32 \mathrm{HST}$ & $34 \mathrm{HST}$ & 36 HST & \\
\hline P1 (tanpa pupuk) & 1,25 & 3,25 & $2,67^{\mathrm{a}}$ & 1,33 & 2,42 & $1,00^{\mathrm{a}}$ \\
\hline P2 (urea 100\%) & 1,83 & 4,08 & $4,92^{\text {cd }}$ & 3,33 & 3,67 & $3,17^{\mathrm{bc}}$ \\
\hline P3 (kipahit 100\%) & 0,67 & 3,75 & $3,58^{\mathrm{abc}}$ & 1,75 & 2,58 & $1,25^{\mathrm{ab}}$ \\
\hline P4 (kipahit $75 \%$ + urea $25 \%$ ) & 2,00 & 3,67 & $3,25^{\mathrm{ab}}$ & 1,17 & 1,42 & $0,75^{\mathrm{a}}$ \\
\hline P5 (kipahit 50\% + urea 50\%) & 1,58 & 3,58 & $3,58^{\mathrm{abc}}$ & 1,75 & 2,42 & $1,67^{\mathrm{abc}}$ \\
\hline P6 (kirinyuh 100\%) & 1,50 & 2,75 & $3,50^{\mathrm{abc}}$ & 2,00 & 2,83 & $1,17^{\mathrm{ab}}$ \\
\hline P7 (kirinyuh $75 \%+$ urea 25\%) & 1,17 & 4,17 & $3,25^{\mathrm{ab}}$ & 1,08 & 1,75 & $0,92^{\mathrm{a}}$ \\
\hline P8 (kirinyuh 50\% + urea 50\%) & 1,50 & 4,58 & $3,92^{\mathrm{abcd}}$ & 2,25 & 3,42 & $3,75^{\mathrm{c}}$ \\
\hline P9 (urine 100\%) & 1,25 & 4,92 & $5,75^{\mathrm{d}}$ & 3,83 & 3,33 & $2,50^{\mathrm{abc}}$ \\
\hline P10 (urine $75 \%$ + urea $25 \%$ ) & 0,75 & 3,92 & $4,33^{\mathrm{bcd}}$ & 2,25 & 3,08 & $2,33^{\mathrm{abc}}$ \\
\hline P11 (urine $50 \%$ + urea $50 \%$ ) & 1,83 & 4,92 & $4,75^{\mathrm{bcd}}$ & 3,75 & 4,00 & $3,58^{\mathrm{c}}$ \\
\hline
\end{tabular}

Keterangan: Nilai rata-rata pada kolom yang sama diikuti huruf yang sama tidak berbeda nyata menurut uji DMRT pada taraf $5 \%$

Bobot polong pada panen ke 2 tanaman yang diberi $100 \% \mathrm{R}$ kirinyuh dan urine sapi $(100 \% / 75 \% / 50 \% \quad \mathrm{R})$ tidak berbeda nyata dengan tanaman yang diberi $100 \%$ R urea. Selanjutnya pada panen ke 3, tanaman dengan perlakuan urine sapi $(100 \% / 75 \% / 50 \%$ R) dan komposisi $50 \%$ kirinyuh $+50 \%$ urea tidak berbeda nyata dengan $100 \% \mathrm{R}$ urea (Tabel 5). Total bobot polong tanaman yang diberi $100 \% \mathrm{R}$ urea tidak berbeda nyata dengan tanaman yang diberi urine sapi $(100 \% / 75 \% / 50 \% \mathrm{R})$ dan komposisi $50 \%$ kirinyuh $+50 \%$ urea. 
Tabel 5. Produksi tanaman buncis (jumlah polong dan bobot polong)

\begin{tabular}{|c|c|c|c|c|c|c|c|}
\hline \multirow[t]{2}{*}{ Perlakuan } & \multicolumn{3}{|c|}{$\begin{array}{c}\text { Rata - rata } \\
\text { jumlah polong }\end{array}$} & \multicolumn{3}{|c|}{$\begin{array}{c}\text { Rata - rata } \\
\text { bobot polong (g) }\end{array}$} & \multirow[t]{2}{*}{ Total } \\
\hline & 1 & 2 & 3 & 1 & 2 & 3 & \\
\hline P1 (tanpa pupuk) & 2,25 & $1,17^{\mathrm{a}}$ & $2,25^{\mathrm{a}}$ & 8,76 & $2,28^{\mathrm{a}}$ & $5,96^{\mathrm{a}}$ & $17,01^{\mathrm{a}}$ \\
\hline P2 (urea 100\%) & 3,42 & $2,54^{\mathrm{abcd}}$ & $11,58^{\mathrm{d}}$ & 13,32 & $7,25^{\text {bcdef }}$ & $36,43^{\mathrm{c}}$ & $57,00^{\mathrm{c}}$ \\
\hline P3 (kipahit 100\%) & 1,13 & $1,63^{\text {abcd }}$ & $2,17^{\mathrm{a}}$ & 3,81 & $4,19^{\mathrm{abcd}}$ & $7,26^{\mathrm{a}}$ & $15,26^{\mathrm{a}}$ \\
\hline P4 (kipahit $75 \%$ + urea $25 \%$ ) & 3,25 & $1,46^{\mathrm{abc}}$ & $2,67^{\mathrm{a}}$ & 10,65 & $3,46^{\mathrm{abc}}$ & $7,83^{\mathrm{a}}$ & $21,94^{\mathrm{a}}$ \\
\hline P5 (kipahit 50\% + urea 50\%) & 3,25 & $1,21^{\mathrm{ab}}$ & $3,71^{\mathrm{ab}}$ & 11,79 & $2,57^{\mathrm{ab}}$ & $12,23^{\mathrm{ab}}$ & $26,59^{\mathrm{ab}}$ \\
\hline P6 (kirinyuh 100\%) & 1,25 & $2,71^{\mathrm{bcd}}$ & $3,25^{\mathrm{a}}$ & 3,95 & $7,85^{\text {cdef }}$ & $8,73^{\mathrm{a}}$ & $20,53^{\mathrm{a}}$ \\
\hline P7 (kirinyuh 75\% + urea 25\%) & 1,88 & $1,50^{\mathrm{abc}}$ & $3,42^{\mathrm{a}}$ & 5,53 & $3,69^{\mathrm{abcd}}$ & $10,37^{\mathrm{a}}$ & $19,58^{\mathrm{a}}$ \\
\hline P8 (kirinyuh $50 \%+$ urea $50 \%$ ) & 1,54 & $1,75^{\mathrm{abcd}}$ & $7,75^{\text {bcd }}$ & 6,67 & $4,53^{\text {abcde }}$ & $24,63^{b c}$ & $35,83^{\mathrm{bc}}$ \\
\hline P9 (urine $100 \%$ ) & 4,21 & $3,17^{\mathrm{d}}$ & $8,04^{\mathrm{cd}}$ & 15,98 & $10,33^{\mathrm{f}}$ & $24,98^{\mathrm{bc}}$ & $51,29^{c}$ \\
\hline P10 (urine $75 \%$ + urea $25 \%$ ) & 3,50 & $3,13^{\mathrm{d}}$ & $5,08^{\mathrm{abc}}$ & 13,39 & $9,83^{\mathrm{ef}}$ & $31,87^{\mathrm{c}}$ & $55,09^{\mathrm{c}}$ \\
\hline P11 (urine $50 \%$ + urea 50\%) & 3,29 & $2,88^{\mathrm{cd}}$ & $10,58^{\mathrm{d}}$ & 14,03 & $8,80^{\text {def }}$ & $35,64^{\mathrm{c}}$ & $58,47^{\mathrm{c}}$ \\
\hline
\end{tabular}

Keterangan: Nilai rata-rata pada kolom yang sama diikuti huruf yang sama tidak berbeda nyata menurut uji DMRT pada taraf $5 \%$

Bobot basah tanaman buncis nyata dipengaruhi oleh komposisi pupuk $\mathrm{N}$. Tanaman yang diberi $100 \% \mathrm{R}$ urine sapi dan komposisi 50\% kirinyuh/urine sapi + $50 \%$ urea tidak berbeda nyata dengan tanaman yang diberi $100 \% \mathrm{R}$ urea (Tabel $6)$.
Bobot kering tanaman buncis nyata dipengaruh oleh komposisi pupuk. Tanaman yang diberi 100\% R urine sapi dan kombinasi $50 \% \mathrm{R}$ kirinyuh / urine sapi $+50 \% \mathrm{R}$ urea tidak berbeda nyata dengan tanaman yang diberi $100 \% \mathrm{R}$ urea (Tabel 6).

Tabel 6. Bobot basah tanaman

\begin{tabular}{|c|c|c|c|c|c|c|}
\hline \multirow{2}{*}{ Perlakuan } & \multicolumn{3}{|c|}{ Rata-rata bobot basah (g) } & \multicolumn{3}{|c|}{ Rata-rata bobot kering (g) } \\
\hline & Total & Tajuk & Akar & Total & Tajuk & Akar \\
\hline P1 (tanpa pupuk) & $38,68^{\mathrm{a}}$ & $35,51^{\mathrm{a}}$ & $3,16^{\mathrm{abc}}$ & $4,98^{\mathrm{a}}$ & $4,48^{\mathrm{a}}$ & $0,50^{\mathrm{a}}$ \\
\hline P2 (urea $100 \%$ ) & $88,16^{\text {de }}$ & $83,40^{\text {de }}$ & $4,75^{\mathrm{ef}}$ & $14,38^{\mathrm{d}}$ & $13,21^{\mathrm{d}}$ & $1,17^{\mathrm{d}}$ \\
\hline P3 (kipahit 100\%) & $57,15^{\mathrm{abc}}$ & $53,53^{\mathrm{abc}}$ & $3,63^{\text {bcde }}$ & $7,38^{\mathrm{ab}}$ & $6,76^{\mathrm{ab}}$ & $0,62^{\mathrm{ab}}$ \\
\hline P4 (kipahit $75 \%$ + urea 25\%) & $46,37^{\mathrm{ab}}$ & $42,81^{\mathrm{a}}$ & $3,56^{\text {abcde }}$ & $6,66^{\mathrm{ab}}$ & $5,98^{\mathrm{ab}}$ & $0,68^{\mathrm{abc}}$ \\
\hline P5 (kipahit 50\% + urea 50\%) & $54,63^{\mathrm{abc}}$ & $51,38^{\mathrm{abc}}$ & $3,25^{\mathrm{abcd}}$ & $7,77^{\mathrm{ab}}$ & $7,13^{\mathrm{ab}}$ & $0,64^{\mathrm{abc}}$ \\
\hline P6 (kirinyuh $100 \%$ ) & $45,61^{\mathrm{a}}$ & $42,65^{\mathrm{a}}$ & $2,96^{\mathrm{ab}}$ & $5,96^{\mathrm{ab}}$ & $5,38^{\mathrm{ab}}$ & $0,58^{\mathrm{ab}}$ \\
\hline P7 (kirinyuh $75 \%+$ urea $25 \%$ ) & $46,35^{\mathrm{ab}}$ & $43,90^{\mathrm{ab}}$ & $2,45^{\mathrm{a}}$ & $7,01^{\mathrm{ab}}$ & $6,26^{\mathrm{ab}}$ & $0,75^{\mathrm{abc}}$ \\
\hline P8 (kirinyuh $50 \%+$ urea $50 \%$ ) & $81,91^{\mathrm{de}}$ & $77,50^{\text {de }}$ & $4,87^{\mathrm{f}}$ & $13,02^{\mathrm{cd}}$ & $11,80^{\mathrm{cd}}$ & $1,22^{\mathrm{d}}$ \\
\hline P9 (urine $100 \%$ ) & $75,13^{\text {cde }}$ & $70,98^{\text {cde }}$ & $4,15^{\text {def }}$ & $12,02^{\mathrm{cd}}$ & $11,13^{\mathrm{cd}}$ & $0,89^{\mathrm{bcd}}$ \\
\hline P10 (urine $75 \%$ + urea $25 \%$ ) & $68,34^{\mathrm{bcd}}$ & $64,73^{\text {bcd }}$ & 3,62abcde & $9,43^{\mathrm{abc}}$ & $8,69^{\mathrm{bc}}$ & $0,73^{\mathrm{abc}}$ \\
\hline P11 (urine $50 \%$ + urea $50 \%$ ) & $94,31^{\mathrm{e}}$ & $90,42^{\mathrm{e}}$ & $3,89^{\text {cde }}$ & $14,69^{d}$ & $13,71^{\mathrm{d}}$ & $0,98^{\mathrm{cd}}$ \\
\hline
\end{tabular}

Keterangan: Nilai rata-rata pada kolom yang sama diikuti huruf yang sama tidak berbeda nyata menurut uji DMRT pada taraf $5 \%$

\section{Pembahasan}

Pemberian pupuk nitrogen meningkatkan pertumbuhan tanaman buncis. Menurut Rohmawati (2013) nitrogen berperan pada pembentukan bagian-bagian vegetatif tanaman seperti daun, batang dan akar. Tanaman yang diberi urine sapi $(100 \% \mathrm{R} / 75 \% \mathrm{R} / 50 \% \mathrm{R})$ tidak berbeda nyata dengan tanaman yang diberi $100 \%$ R urea. Hal ini sejalan dengan Nathania et al. (2012) yang menyatakan urine memiliki keunggulan karena mengandung berbagai unsur hara makro yaitu N, P, K dan zat pengatur tumbuh. Urine sapi diduga mampu menggantikan unsur hara makro yang hilang dari Urea 
serta memenuhi unsur mikro yang tidak terdapat pada Urea. Salisbury dan Ross (1995) menyatakan bahwa pupuk organik cair selain mengandung $\mathrm{N}$ juga mengandung unsur hara mikro antara lain unsur $\mathrm{Mn}, \mathrm{Zn}$, dan B. Unsur hara mikro tersebut berperan sebagai katalisator dalam proses sintesis protein dan pembentukan klorofil.

Jumlah daun tanaman yang diberi urine sapi memberikan hasil yang tidak berbeda nyata dengan tanaman yang diberi urea $100 \%$ R. Triwasana (2009) menyatakan bahwa pemberian urine sapi mampu memberikan jumlah daun lebih banyak. Pada dasarnya urine sapi memiliki sifat mirip dengan urea dalam penyediaan $\mathrm{N}$ bagi tanaman yaitu $\mathrm{N}$ diserap dalam bentuk amonium, sehingga mudah diserap oleh tanaman. Harjadi (1979) menyatakan bahwa salah satu fungsi $\mathrm{N}$ bagi tanaman adalah untuk merangsang aktivitas meristematis.

Pertumbuhan luas daun tanaman dipengaruhi unsur N (Sarief 1985). Pembesaran lingkar batang buncis (diameter) dipengaruhi oleh auksin yang terdapat pada urin sapi. Liu et al. (2012) menyatakan IAA (Indole-3-Acetic-Acid) bekerja untuk pembelahan, pemanjangan dan diferensiasi sel. IAA meningkatkan peregangan dinding sel dalam koleoptil pada batang muda yang masih berkembang. Tinggi dan pertambahan diameter batang buncis diduga dari proses penyerapan hara melalui akar secara efektif dan dialokasikan ke seluruh tanaman. Tanaman yang tidak diberi pupuk memiliki hasil yang tidak berbeda nyata dengan beberapa perlakuan POC, diduga tanah yng digunakan memiliki kandungan hara yang cukup tinggi.

Pemberian POC konsentrasi tinggi sampai batas tertentu akan menyebabkan peningkatan hasil dan pada konsentrasi yang melebihi batas tertentu akan menyebabkan hasil menjadi menurun. Dalam proses pertumbuhan beberapa faktor lingkungan dapat menjadi pembatas atau dapat menghambat pertumbuhan.
Batas toleransi tanaman memiliki batas maksimum dan minimum. Titik maksimum atau minimum merupakan titik ketika suatu tumbuhan dapat mengalami keracunan pada tubuh organisme, sehingga yang terbaik adalah titik pertengahan yaitu tidak mendekati atau menjauhi titik minimum atau maksimum. Pemberian POC dengan konsentrasi $50 \%$ lebih baik dibandingkan dengan konsentrasi $25 \%$ dan $75 \%$ karena konsentrasi $50 \%$ merupakan konsentrasi yang sesuai dan seimbang dengan kebutuhan tanaman buncis. Berdasarkan hukum minimum Liebig dan hukum toleransi Shelford yang selanjutnya dapat dipahami konsep faktor pembatas (limiting factor), yaitu keadaan yang mendekati atau melampaui ambang batas toleransi suatu kondisi.

Bunga dan polong buncis merupakan parameter untuk menentukan kemampuan tanaman buncis dalam berproduksi pada lingkungan tumbuh. Hasil tanaman dapat ditentukan oleh respon tanaman terhadap hara yang berhubungan dengan kemampuan beradaptasi dengan lingkungan. Jika tanaman mampu menghasilkan polong yang banyak berarti lingkungan tumbuh dan kebutuhan nutrisi pada tanah telah sesuai.

Produksi tanaman dapat diprediksi baik apabila pertumbuhan vegetatif tanaman baik. Semakin besar pertumbuhan vegetatif yang berfungsi sebagai penghasil asimilat (source) akan meningkatkan pertumbuhan organ pemakai (sink) yang akhirnya akan memberikan hasil yang semakin besar pula. Apabila tanaman tidak mampu membentuk asimilat secara cukup maka kompetisi antara organ vegetatif dan generatif dapat terjadi (Triwulaningrum 2009). Pertumbuhan dan perkembangan buah memerlukan asimilat dalam jumlah yang cukup. Bila pertumbuhan vegetatif dominan, maka hasil generatif akan berkurang (Gardner et al. 1991).

POC kipahit, kirinyuh dan urine sapi yang diberikan mampu menyuplai unsur hara yang diserap tanaman terutama 
nitrogen secara maksimal dan disalurkan ke tanaman secara baik. Selain hara dalam tanaman, jumlah air yang terkandung di dalam tanaman dapat memberi pengaruh pada bobot tajuk tanaman buncis. Bobot basah tanaman dipengaruhi oleh kadar air yang terdapat pada jaringan atau organ tubuh tanaman, unsur hara, dan bahan organik yang terkandung dalam suatu tanaman. Bobot segar tajuk dan bobot kering tajuk terendah didapat pada tanaman yang tidak mendapat pupuk selama pertumbuhan, sehingga tanaman menjadi kerdil dan kurang nutrisi.

Pada dasarnya produksi tanaman buncis akan maksimal apabila unsur hara $\mathrm{N}, \mathrm{P}$ dan $\mathrm{K}$ tercukupi sesuai kebutuhan tanaman. Menurut Lakitan (2007) unsur nitrogen meningkatkan pembentukan protein, enzim dan sebagai unsur pembentuk klorofil, selain itu ketersediaan

\section{DAFTAR PUSTAKA}

Adi IB. 2013. Kajian preparasi dan kondisi optimum ekstraksi bionutrien berbasis tanaman SO- 23. [Skripsi]. Bandung: Universitas Pendidikan Indonesia.

Atmojo SW. 2003. Peranan Bahan Organik terhadap Kesuburan Tanah dan Upaya Pengelolaannya. Surakarta: Sebelas Maret University Press.

[BPS] Badan Pusat Statistik. 2015. Tabel impor menurut komoditi tahun 2014. Available online at https://www.bps.go.id/all_new_tem plate.php. (Desember 2018).

[DJH] Direktorat Jenderal Hortikultura. 2018. Produksi Tanaman Sayuran di Indonesia Tahun 2014-2017. Available online at http://hortikultura2.pertanian.go.id/ produksi/sayuran.php. (Desember 2018).

Gardner FP, Pearce FB, Mitchel RL. 1991. Fisiologi Tanaman Budidaya.
$\mathrm{N}$ dapat meningkatkan serapan $\mathrm{P}$. Pemberian $\mathrm{N}$ pada tanah yang dipupuk akan lebih melarutkan $\mathrm{P}$ sehingga unsur $\mathrm{P}$ lebih tersedia dan dapat dimanfaatkan oleh tanaman untuk pembentukan polong (Hervina et al. 2015).

\section{KESIMPULAN}

Hasil penelitian membuktikan bahwa aplikasi POC sumber nitrogen memiliki hasil yang tidak berbeda nyata dengan aplikasi urea. Aplikasi kirinyuh 50\% + urea $50 \%$ dan urine sapi $(100 \% / 75 \% / 50 \%$ R) memiliki hasil yang baik dalam pertumbuhan vegetatif dan produksi tanaman, sehingga dapat digunakan sebagai alternatif pengganti urea untuk menerapkan sistem pertanian ramah lingkungan.

Penerjemah Herawati Susilo. Yogyakarta: UII Press.

Gonzalez-Dugo V, Durand J, Gastal F. 2010. Water deficit and nitrogen nutrition of crops. A review. Agron Sustain Dev. 30(3): 529-544.

Hakim N, Agustian, Mala Y. 2012. Application of organic fertilizer tithonia plus to control iron toxicity and reduction commercial fertilizer application on new paddy field. $J$ Trop. Soils. 17:135-142.

Harjadi. 1979. Pengantar Agronomi. Jakarta: PT Gramedia.

Hervina R. 2015. Pengaruh Pemberian Pupuk Cair Limbah Biogas dan Pupuk N, P, K terhadap Pertumbuhan dan Produksi Kedelai Edamame [Skripsi]. Pekanbaru: Fakultas Pertanian-Universitas Riau.

Lakitan B. 2007. Dasar-Dasar Fisiologi Tumbuhan. Jakarta: PT. Raja Grafindo Persada.

Lory JA, Olson KC, Zumbrunnen C. 2006. Calculating Fertilizer Value of 
Supplemental Feed for Cattle on Pasture. Extension publications (MU) University of Missouri Columbia.

Liu Bing, Zehui Z, Kejian D. 2012. Efficient One-Pot synthesis of 5 (Ethoxymethyl)furfural from Fructose Catalyzed by a Novel Solid Catalyst. American Chemical Society. Ind. Eng. Chem. Res. 2012, 51, 15331-15336.

Matsi T. 2012. Liquid cattle manure application to soil and its effect on crop growth, yield, composition, and on soil properties. inSoil Fertility Improvement and Integrated Nutrient Management A Global Perspective, Whalen J (Editor). InTech 97-118.

Nathania B, Sukewijaya IM, Sutari NWS. 2012. Pengaruh Aplikasi Biourine Gajah terhadap Pertumbuhan dan Hasil Tanaman Sawi Hijau (Brassica juncea 1.). J. Agroekoteknologi Tropika 1(1):7285.

Pitojo S. 2004. Seri Penangkaran Benih Buncis. Yogyakarta: Kanisius.

Rohmawati I. 2013. Penentuan dosis pemupukan $\mathrm{N}, \mathrm{P}$ dan $\mathrm{K}$ pada budidaya katuk (Sauropus androgynus (L.) Merr.). [Tesis]. Bogor: Sekolah Pascasarjana Institut Pertanian Bogor.

Salisbury BF, Ross WC 1995. Fisiologi Tumbuhan. Bandung: Institut Teknologi Bandung.

Sarief S. 1985. Kesuburan dan Pemupukan Tanah Pertanian. Bandung: CV. Pustaka Buana.

Supriyanto, Muslimin, Umar H. 2014. Pengaruh berbagai dosis pupuk organik cair urin sapi terhadap pertumbuhan semai jabon merah (Anthocephalus macrophyllus (Roxb.) Havil). Warta Rimba. 2(2): 149-157.

Sutanto R. 2002. Penerapan Pertanian Organik. Yogyakarta: Kanisius.

Triwasana LRD. 2009. Pengaruh Dosis Pupuk Urea dan Urin Sapi pada Tanaman Kacang Hijau (Vigna radiata L.). Fakultas Pertanian Universitas Brawijaya. Malang. $J$ Produksi Tanaman. 2(2):7-11.

Triwulaningrum W. 2009. Pengaruh Pemberian Pupuk Kandang Sapi dan Pupuk Fosfor Terhadap Pertumbuhan dan Hasil Buncis Tegak (Phaseolus vulgaris L.). [Skripsi]. Malang: Fakultas Pertanian-Universitas Brawijaya. 